NBER WORKING PAPER SERIES

\title{
IS JAPAN'S INNOVATIVE CAPACITY IN DECLINE?
}

\author{
Lee Branstetter \\ Yoshiaki Nakamura \\ Working Paper 9438 \\ http://www.nber.org/papers/w9438 \\ NATIONAL BUREAU OF ECONOMIC RESEARCH \\ 1050 Massachusetts Avenue \\ Cambridge, MA 02138 \\ January 2003
}

This paper was prepared for the volume on Structural Impediments to Growth that is being edited by Magnus Blomstrom, Jennifer Corbett, Fumio Hayashi and Anil Kashyap for the NBER and will be published by the University of Chicago Press. We thank the conference organizers, the conference participants, Masahiko Aoki, Ashish Arora, Amar Bhide, Hiroyuki Odagiri, David Weinstein, and Akira Goto for extremely helpful comments. We are also grateful to a number of Japanese corporate R\&D managers and industry observers based in Japan and overseas for their candid responses to our questions on Japanese firm R\&D activity. By prior agreement, their names must remain confidential. We are grateful to Takuji Saito (Hitotsubashi University), Masami Imai (University of California, Davis), and Yoshiaki Ogura (Columbia University) for excellent research assistance, and to the Research Institute of Economy, Trade, and Industry, the National Science Foundation, and the Columbia Center on Japanese Economy and Business for financial support. All errors remain our own responsibility. The views expressed herein are those of the authors and not necessarily those of the National Bureau of Economic Research.

(C2003 by Lee Branstetter and Yoshiaki Nakamura. All rights reserved. Short sections of text not to exceed two paragraphs, may be quoted without explicit permission provided that full credit including . notice, is given to the source. 
Is Japan's Innovative Capacity in Decline?

Lee Branstetter and Yoshiaki Nakamura

NBER Working Paper No. 9438

January 2003

JEL No. I24, O32, O33

\section{$\underline{\text { ABSTRACT }}$}

This paper investigates changes in the output and productivity of research and development activities in Japanese manufacturing firms over the 1980s and 1990s. Evidence from aggregate patent and R\&D statistics and a micro-level analysis of R\&D productivity at the firm-level suggest that there has been a slowdown in the growth of Japanese research productivity in the 1990s. The paper goes on to suggest possible explanations for this slowdown and reviews some of the steps Japanese firms are taking to increase the effectiveness of their R\&D. The paper presents empirical evidence concerning the impact of one of these steps - the creation of technology alliances with U.S. firms - on Japanese innovative output.

Lee Branstetter

Associate Professor

Columbia Business School

Uris 815

3022 Broadway

New York, NY 10027

and NBER

1gb2001@columbia.edu
Yoshiaki Nakamura

Director for General Affairs Division

Kanto Bureau of Economy, Trade, and Industry

METI

2-11, Kamiochiai, Saitama-shi

Saitama, Japan

nakamura-yoshiaki-yn@meti.go.jp 
During the 1980s a significant source of Japanese growth - and a major source of concern for Japan's trading partners - was the widely admired innovative capacity of Japanese firms. Over the course of the decade, Japanese firms entered and successfully competed in hightech industries that had formerly been the preserve of US and European multinationals. Japanese firms' expanding innovative capacity was clearly reflected in aggregate statistics on R\&D expenditures, patenting, and productivity, all of which showed a steady increase in R\&D input and output. A mid-decade study by the National Academy of Engineering (1987) concluded that Japan was superior to the United States in 25 of 34 "critical" technologies. 1

This situation changed quite dramatically over the course of the 1990s. R\&D spending by the private sector in Japan has stagnated during the Heisei recession. Measures of R\&D output growth in Japan have declined relative to the United States and relative to Japanese historical trends. There is a widespread sense among Japanese R\&D managers, industry observers, and government officials that the Japanese approach to technological innovation is no longer working effectively, and fundamental reform of the national innovation system must take place. $^{2}$

It is important to note that technological factors have not been the primary drivers of the Heisei recession. Rather, the collapse of asset prices, the resulting crisis in the banking system, and the inappropriate macroeconomic policy responses of the Japanese government since the early 1990s have arguably been the primary cause. ${ }^{3}$ However, the implications of the apparent decline in Japanese innovative capacity are potentially quite serious for Japan's long-run economic prospects. When normal growth resumes, the maximum sustainable rate will depend in part on the ability of Japanese firms to develop and deploy new technology. If Japan's innovative capacity is growing at a slower rate than in past decades, this could limit Japan's future prospects.

This chapter examines Japan's R\&D performance from the early 1980s using several complementary modes of analysis. First, we examine evidence from aggregate economic statistics concerning changes in Japanese R\&D. Second, we analyze comprehensive data on

\footnotetext{
${ }^{1}$ See Okimoto and Saxonhouse (1987), Arison et al (1992), and Mansfield (1988). A book-length treatment is Goto (1993).

${ }^{2}$ For a recent English article which quotes pessimistic Japanese experts at length on this subject, see Normile (2002)

3 For research supporting this view, see Posen (1998).
} 
R\&D inputs and outputs for a panel of nearly 200 Japanese firms. Microeconometric analysis of this data set allows us to examine where any downturn in R\&D activity is concentrated, what Japanese firms are themselves doing to rectify the downturn in performance, and what effects these steps have had to date. Third, we relate the results of 10 interviews of corporate R\&D managers and informed industry observers concerning their perceptions of changes in Japanese innovative capacity and the reasons for these changes.

The main empirical contribution of this chapter is to document, at the micro level and the aggregate level, a slowdown in the growth rate of Japanese research productivity. We find that after a decade of convergence with the United States in terms of R\&D inputs and outputs in the 1980s, Japanese and US innovation trends have diverged sharply in the 1990s. Measured in a common currency, real R\&D outlays in Japan have grown much more slowly than in the United States. The gap in patent output that was closing rapidly in the 1980 s began expanding again in the 1990s.

Firm-level data show evidence of a slowdown in the growth of R\&D productivity in Japan in the 1990s, controlling for R\&D spending and other firm attributes. This slowdown does not affect all firms equally. By and large, the research productivity of the electronics industry, broadly defined, has continued to grow in line with the trends of the 1980s and early 1990s. On the other hand, firms outside the electronics industry have performed less well.

Why has Japanese R\&D productivity grown more slowly in the 1990s? A fullfledged investigation of this question is beyond the scope of this paper. However, drawing on our interviews with Japanese R\&D managers and evidence from other economic studies, we are able to present some possible explanations. As they have reached the technology frontier, Japanese firms have had to re-orient their R\&D efforts from the application and refinement of existing, relatively well-developed technology to the creation of more fundamental breakthroughs. ${ }^{4}$

The shortage of PhD-level engineers and the relative weakness of Japanese academic science may have inhibited the effectiveness of such technologically more ambitious R\&D in Japan. Furthermore, attempts to create large, centralized corporate labs focused on more basic R\&D have apparently run into the same problems that large-scale US corporate R\&D labs were criticized for in the 1980s, including a lack of focus on the needs of a rapidly

\footnotetext{
${ }^{4}$ For an insightful perspective on this shift, see Goto (1997).
} 
evolving marketplace. ${ }^{5}$ Finally, the absence of a venture capital industry and the types of institutions that support start-ups in the United States seem to have made it difficult for established Japanese firms to partner in product development with more entrepreneurial and efficient smaller firms.

Having noted the problems, Japanese R\&D managers are trying to respond to them. Conversations with Japanese R\&D managers reveal several steps firms are taking to restructure $R \& D$ operations and improve research productivity. This chapter presents evidence on the impact of one such step - the forging of technology alliances with US firms. We find that this strategy leads to increased flows of technological information to Japanese firms. We also present evidence that is consistent with the view that these increased knowledge flows raise overall inventive productivity. This suggests that at least some of the responses of the private sector are having the desired impact.

In terms of public policy implications, we note that the Japanese government has undertaken a number of reforms to help Japanese firms make the leap from more applied to more basic R\&D, including strengthening the Japanese patent system, increasing public expenditures on research, expanding graduate education in Japan, and removing some of the legal and regulatory barriers to the formation of venture capital backed start-up firms. However, in the context of a stagnating economy, many of Japan's firms have been forced to limit their R\&D spending and shift R\&D personnel into operational functions - and the longer the recession lasts the more likely it is that these steps could have long-lasting negative effects on research productivity. Perhaps the most important step the Japanese government can take in the short-run to revive Japan's innovative performance is to stimulate macroeconomic growth.

\section{Comparative Perspective}

After nearly a decade of stagnation in Japan, it is sometimes difficult to recall the unease even fear - that Japan's seemingly unstoppable economic advance during the 1980s once generated among US industrialists and policy makers. To set the stage for the analysis here, it is worth reviewing some of the evidence on Japan's expanding technological capability.

\footnotetext{
${ }^{5}$ See Rosenbloom and Spencer (1996).
} 
As the Japanese economy expanded in the 1980s, R\&D spending steadily increased. ${ }^{6}$ Moreover, the effectiveness with which Japanese firms applied this R\&D expenditure to successful generation of useful inventions also seemed to be increasing. Researchers noted that Japanese firms produced more patent applications per R\&D dollar than US firms, and that this ratio was not declining, as it seemed to be in the rest of the industrialized world. ${ }^{7}$

Scholars familiar with the idiosyncratic features of the Japanese patent system prior to its substantial reform in 1988 were quick to point out that many more patent applications were required to protect the same amount of intellectual property in Japan, and that straightforward comparisons of Japanese and US patent counts were likely to exaggerate Japan's technological prowess.

However, because of the importance of the US market, Japanese firms were also quite aggressive about patenting in the United States. Over the course of the late 1970s and 1980s, Japanese firms rapidly increased their level of US patenting in absolute numbers and relative to US counterparts. Given that the two sets of firms were competing under the same patent system with the same set of rules and examiners, this seemed to buttress the case that the Japanese were closing the technological gap with their US rivals.

Careful micro studies of Japanese innovation, such as Mansfield (1988), also suggested that Japan's R\&D capability was formidable, particularly its applied R\&D capability. Mansfield's statistical results suggested that applied R\&D expenditure in Japan had a much stronger impact on firm-level total factor productivity (TFP) growth than it did in the United States. On the other hand, basic R\&D spending seemed to be far less effective. Likewise, a comparative analysis of product development in the automobile industry in Japan, Europe, and the United States by Clark and Fujimoto (1991) carefully documented Japanese firms' enormous lead over rivals in terms of the resource cost of product development.

The picture of expanding relative Japanese technological capability changed substantially in the 1990s, as Figure 1 shows. US private sector R\&D spending grew quite rapidly in real terms, reflecting robust macroeconomic growth and the especially rapid growth of high-tech industries. In striking contrast, the increase in Japan was modest, and spending actually declined in two years. The difference in trends in R\&D inputs is reflected

\footnotetext{
${ }^{6}$ Time-series on Japanese real R\&D spending appears in Gijutsu Yoran (2000).

${ }^{7}$ See Okimoto and Saxonhouse (1987) for a discussion of these issues.
} 
in the aggregate statistics on R\&D outputs. For instance, the counts of patents taken out by Japanese firms in the United States grew much more slowly after 1990 than in the 1980s, whereas the reverse was true for the United States. Figure 2 illustrates this divergence, aggregating across all US patent classes.

Figure 3 illustrates a similar pattern of convergence followed by divergence within the cluster of patent classes that are most closely connected to computers and information technologies. Patenting levels converged up to 1988, but then, from 1993 US firms' patenting in these fields exploded, greatly outstripping the growth in Japanese patents for the rest of the $1990 \mathrm{~s}^{8}{ }^{8}$ It is important to note that the relative decline in patents is seen not only in the US patent system. Looking at world-wide patent applications, there have been striking increases in the quantity of applications from inventors based in the United States and Europe, but not in Japan. Figure 4 illustrates the trends.

This review of aggregate statistics suggests that there is something real behind the steadily more insistent concerns being raised in Japan about the Japanese national innovation system and its comparative performance. ${ }^{9}$ However, it also raises an important question. Is the relative decline in Japanese innovative output simply a function of relative declines in R\&D spending, or has there been a slowdown in the growth of Japanese firms' innovative capacity, even after controlling for changes in R\&D spending? This question is addressed in the next section.

\section{A Micro Analysis Of R\&D Productivity}

In this section, we utilize data collected on $R \& D$ inputs and outputs at the level of the firm to

\footnotetext{
${ }^{8}$ Posen (2001) stresses that many of the top 10 patenting firms in the United States are Japanese multinationals. Unfortunately, the strong performance of these firms is evidently not representative of the innovative performance of their industries.

${ }^{9}$ For a forceful presentation of the view that Japan's relative innovative performance has not changed since the 1980s, see Posen (2001). While we strongly agree with Posen's main point - that Japan's poor macroeconomic performance in the 1990s has little direct connection with the efficiency of its R\&D activity - we believe that his rather optimistic view of the Japanese innovation system is not consistent with some of the evidence presented in this paper.
} 
estimate a simple "knowledge production function." 10 Let innovation for the $i$ th firm be a function of its $R \& D$ input, such that

$N_{i t}=R_{i t}^{\beta} \Phi_{i t}$

where

$\Phi_{i t}=e^{\sum_{c} \delta_{c} D_{i c}} e^{\sum_{t} \gamma_{t} T_{t}} e^{u_{i}}$

The $\delta$ s can be thought of as exogenous differences in the "technological opportunity" across $c$ different technological fields that are stable across time. The $\gamma \mathrm{s}$ can be thought of as changes in the overall effectiveness of the R\&D process, common to all fields, over time. These latter coefficients will be crucial to our analysis. We want to observe whether, conditional on R\&D spending, the overall effectiveness of private sector innovative activity is increasing, decreasing, or unchanging over time. Our inference concerning this will be based on the pattern revealed by the $\gamma$ coefficients.

Taking the logs of both sides of (2) yields the following log-linear equation

$n_{i t}=\beta r_{i t}+\sum_{t} \gamma_{t} T_{t}+\sum_{c} \delta_{c} D_{i c}+\varepsilon_{i t}$

In (3), $n_{i t}$ is innovation, $r_{i t}$ is the firm's own R\&D investment, $D$ s are dummy variables to control for differences in the propensity to generate new knowledge across technological fields (indicated by the subscript $c$ ), $T$ s are year dummies, and $\varepsilon$ is an error term.

\subsection{Measuring Innovation}

\footnotetext{
${ }^{10}$ The empirical methodology here borrows heavily from Branstetter and Sakakibara (1998) and Branstetter (2001a), which, in turn, are strongly influenced by Jaffe (1986). The exposition follows those earlier papers quite closely.
} 
There are no direct measures of innovation, but if some fraction of new knowledge is patented, such that the number of new patents generated by the $i$ th firm is an exponential function of its new knowledge,

$$
P_{i t}=e^{\sum_{c}^{c} \alpha_{c} D_{i c}} e^{\xi_{i}} N_{i t}
$$

then the production of new knowledge can be proxied by examining the generation of new patents. Taking the logs of both sides of (4) and substituting into (3) yields

$$
p_{i t}=\beta r_{i t}+\sum_{t} \gamma_{t} T_{t}+\sum_{c} \delta_{c} D_{i c}+\mu_{i t}
$$

where $p_{i t}$ is the log of the number of new patents and the other variables are as before, except for the error term. We allow the new error term to contain firm fixed effects, such that there can be time-invariant differences in the propensity to patent among firms within industries. Because firms in our sample do not change their primary industry affiliation over time, the industry effect would "fall out" with the firm fixed effect in a standard fixed effects regression.

As written, equation (5) suggests that the log of patent counts should be our dependent variable. Some firms in our sample are observed to take out zero patents in a given year, which creates an obvious problem because one cannot take the log of zero. In the earlier micro R\&D-patents literature, it was customary to take the log of the count of patents plus 1 to get around this. However, this somewhat arbitrary transformation of the dependent variable could bias the results.

Instead, we have used count data statistical models to conduct our analysis. In particular, we use the fixed effects negative binomial estimator developed by Hausman, Hall, and Griliches (1984) to estimate a version of (5) in which a 0 realization of the dependent variable does not pose any kind of mathematical problem. 


\subsection{Data Gathering}

To implement this approach, we collected data on the patents granted to Japanese firms in the United States (dated by year of patent application), patents applied for by Japanese firms in Japan, R\&D spending, and industry affiliation. Further information on data sources and construction is provided in the Appendix.

Is our sample reasonably representative of Japanese industrial R\&D activity, and does this degree of "representativeness" change over time? In Japan, R\&D spending and patenting have historically been highly concentrated in the larger industrial firms. A panel of large industrial firms in the United States would become steadily less representative of US patenting over the 1990s because of the rising role of universities and high-tech start-up firms in US inventive activity. ${ }^{11}$ In Japan, there is no evidence of a similar shift. ${ }^{12}$ Because our sample includes most of the leading R\&D-performing firms in Japan, we believe it is representative of industrial $R \& D$ activity.

For our purposes, the use of US patents is actually the preferred metric of innovative output. A major patent reform in Japan in 1988 allowed Japanese firms to change the number of claims per patent, making it at least theoretically possible for Japanese firms to protect the same amount of intellectual property with a smaller number of patents. It is thus difficult to draw long-term inferences about changes in research productivity using Japanese patent application counts because the relationship between innovations and patents has shifted over time. ${ }^{13}$ There was no such change in the US patent system over our sample period.

Furthermore, Japanese firms tended to submit patent applications to the US Patent and Trademark Office for the ideas they perceive, at least ex ante, to have the most promise, so that a US patent count series represents a "quality-adjusted" measure of innovative output. Finally, thanks to the availability of US patent data in electronic form, it is possible to conduct an additional "quality adjustment" by measuring the number of citations received by a patent from subsequently granted patents over some fixed time period - in our case, four years.

\footnotetext{
${ }^{11}$ See Hicks et al (2001), who document the increased role of smaller firms and universities in US patenting.

${ }^{12}$ Goto (1997) affirms this and comments on its implications for the future of industrial innovation in Japan.

${ }^{13}$ For an empirical study of the effects of this patent reform on Japanese innovation, see Sakakibara and Branstetter (2001).
} 


\subsection{Drawing Inferences from the Data}

The first column of Table 1 presents results of a fixed effects negative binomial regression of US patent counts on firm R\&D spending and our year dummy variables. Controlling for R\&D spending at the firm level, the coefficients on the time dummies trace out changes in the level of R\&D output that are common to all firms. In other words, it gives us a sense of how innovative output is changing, on average, after we have controlled for inputs.

Figure 5 graphs the pattern traced out by the time dummies, along with the $95 \%$ confidence bounds. The picture that emerges is fairly striking. From the mid-to-late 1980s, one sees a sharp increase in average innovative output. This growth largely ceases in the early 1990s, suggesting that R\&D productivity reached a plateau around 1990 and grew little thereafter. $^{14}$

Is this cessation of $R \& D$ productivity growth real or an artifact of the data? The substitution of observable patents for unobservable innovation creates some problems for our statistical inference. The $\gamma$ coefficients measure not just changes in the productivity of R\&D activity over time, but also changes in the propensity to patent in the United States over time. It could be, for instance, that Japanese firms are generating larger numbers of innovations over time but, in order to economize on the costs of protecting their intellectual property rights, they are being more selective about which patents they take out in the United States. In other words, a count-based output measure would show a flattening of innovative productivity where there was none. ${ }^{15}$ To try to get around this possibility, we constructed a measure of patent output in which we adjusted for the number of citations received by each patent up to four years after it was granted. If the number of patents taken out in the United States is going down because only the upper tail of the quality distribution of innovations is actually being patented, then an outcomes measure that controls for innovation quality would be less likely to generate a spurious result of flat productivity growth.

The second column of Table 1 presents results from such a regression. Figure 6 graphs the coefficients along with their $95 \%$ confidence bounds. The picture that emerges is similar to that in Figure 5.

\footnotetext{
${ }^{14}$ Including deflated sales as an additional regressor yields results qualitatively similar to those presented here.

${ }^{15}$ We thank Hiroyuki Odagiri for stressing this point.
} 
The next set of regression results segments our sample into industry groups to see how research productivity trends differed among industries. Figure 7 indicates that the research productivity of the electronics industry, broadly defined, has continued to grow through the mid-1990s more or less in line with the trends of the 1980s. In contrast, there is a decline in research productivity for manufacturing firms outside the electronics industry. That is, controlling for innovative inputs, these firms are generating less innovative output, on average, then they were in the late 1980s. Regression results based on citation-adjusted patent output measures indicate a similar pattern.

Table 2 presents results based on Japanese patent applications. If one pools data across all firms, these data suggest a continuing rise in innovative productivity through the mid 1990s, but a slowdown in growth relative to the trends of the 1980s. Splitting the sample along industry lines indicates electronics firms outperformed firms in other industries. In both cases, a slowdown in productivity growth is evident, occurring sooner among firms outside of electronics. While there were substantial increases in R\&D productivity in the early 1990s for electronics firms, the increase is much less impressive outside that sector.

If the number of claims is rising fast enough to offset the slowdown in the growth of patent applications, then one can argue that the data are consistent with increased innovation in both categories. This possibility indicates the need for caution in interpreting results based on Japanese patent data. For a study of Japanese innovation trends in the immediate aftermath of the 1988 patent reform, see Sakakibara and Branstetter (2001).

A breakdown of R\&D productivity trends by firm size suggests that, outside the electronics sector, relatively smaller firms are more likely to show progress in research productivity than larger firms. These findings are not reported here due to space constraints, but they were confirmed using US patent output data as well.

What can we conclude from our preliminary exploration of the firm-level data? Our results suggest that changes in Japan's absolute and relative performance are not simply or solely the result of a decline in firms' R\&D spending. Although we find some evidence of an actual decline in research productivity in some sectors, the more robust result is that the broad-based increase in Japanese research productivity that was so striking in the 1980s largely faded in the 1990s. The exception to this general trend is the electronics sector, which has continued to increase its innovative output, controlling for input. However, continued progress in $R \& D$ productivity in this sector has not prevented Japanese firms from 
falling well their US rivals in such key patent categories as information technology. This may reflect Japanese firms' inability to match their rivals' expanding investments in R\&D.

The stereotype of Japanese firms as effective imitators and implementers rather than innovators may have been accurate in the late 1970s and even the early 1980s, but by the late 1980s many Japanese firms had reached the technological frontier and their continued success increasingly has depended on their ability to advance that frontier. This is captured in our interviews with Japanese R\&D managers and industry observers, conducted in the United States and Japan in 2000 and 2001.

\subsection{The Focus and Structure of R\&D Activity}

Since at least the early 1980s, each interviewed company has made a substantial commitment to R\&D at the technological frontier within its industry. A large central R\&D operation was built up with the aim of creating important technical breakthroughs that could be incorporated into future products. Although our interviewees tended to be corporations recognized as technological leaders within their fields, this change in focus from applied to more basic R\&D also is broadly reflected in larger, more representative surveys. ${ }^{16} \mathrm{~A}$ change in the focus of $R \& D$ was inevitable - at one time, Japanese firms were the global low-cost suppliers of standardized products, but manufacturers in South Korea, Taiwan, and China are increasingly able to undercut Japanese firms. This means that Japanese firms have to compete on the basis of innovative products. ${ }^{17}$ The interviewed R\&D managers are universally dissatisfied with the results of their investment in frontier research. The view within firms seems to be that the central R\&D laboratories have become bureaucratic,

\footnotetext{
${ }^{16}$ See Goto and Nagata (1997), Cohen et al (1997), and the 2000 Gijutsu Yoran for evidence that the distribution of R\&D effort across the categories of basic versus applied R\&D (and process innovation versus product innovation) in the United States and Japan had essentially converged by the mid-1990s.

${ }^{17}$ Goto (1997) offers some useful observations regarding this point.
} 
insular, and unresponsive to the needs of the firm. R\&D management has been unable to effectively translate the basic and frontier research into effective new products. ${ }^{18}$ The critiques of central R\&D operations echo those by US firms in the 1980s regarding their own central R\&D operations: these were often seen as being unable to translate research advances effectively into new products. ${ }^{19}$ In other words, a managerial perception that relative $R \& D$ performance has declined confirms the findings of our statistical analysis.

Our interviewees spoke admiringly of the way their US counterparts restructured their R\&D operations during the 1990s, and most of the interviewed firms were trying to restructure along the lines of the "new" US model. The characteristics of the new structure of R\&D are still emerging, but conversations with Japanese corporate R\&D managers suggest that it includes five main features.

1 Greater reliance on $\mathrm{R} \& \mathrm{D}$ partnerships outside the traditional vertical keiretsu networks within Japan.

2 Greater reliance on foreign (especially US) R\&D partnerships and acquisitions of high-tech firms.

3 Greater emphasis on cooperation with universities, domestic and foreign.

4 A de-emphasis on centralized in-house R\&D and a gradual downsizing of resources invested in central $R \& D$ facilities.

$5 \quad$ Increased interest and investment in "corporate venturing" programs.

Japanese firms, in conscious imitation of their US counterparts, are placing increased emphasis on sourcing useful technologies from outside the firm. These can then be combined with the firm's own technical strengths to generate important new products. This increased "R\&D outsourcing" is probably the over-riding theme guiding departures from the "traditional" model of research. As part of this, because Japan still has relatively few hightech start-ups, and because the quality and level of academic research in Japan typically lags that of the United States, Japanese firms have moved aggressively to expand their efforts to tap US technology networks.

\subsection{Reasons for a Slowdown in R\&D Productivity}

\footnotetext{
${ }^{18}$ An early evaluation of the effectiveness of the build-up in R\&D spending, based on an econometric study of product introductions, is Wakasugi and Koyata (1997).

${ }^{19}$ See Rosenbloom and Spencer (1996).
} 
A full-fledged investigation of the reasons why the innovation trends in the United States and Japan have diverged so sharply is beyond the scope of this chapter, but our exchange with $R \& D$ managers and a review of the related literature suggests some possible explanations.

The nature of Japanese industrial R\&D has clearly changed in terms of its technological focus and its organization. First, Japanese firms have moved from a focus on largely applied R\&D to an effort to generate more fundamental R\&D breakthroughs, bringing them more in line with the US allocation of industrial R\&D effort. Second, in pursuit of this change in focus, Japanese firms have concentrated engineering talent in upgraded central R\&D labs.

Prior research and comments from our interviewees suggest that the shift in R\&D focus may have placed Japanese firms at a relative disadvantage. As Saxonhouse has pointed out for decades, the Japanese higher education system produces far fewer $\mathrm{PhDs}$ in the sciences and engineering than does the US educational system. ${ }^{20}$ Japan has produced many more engineering graduates at the bachelors degree level per capita, and this may have been sufficient to propel Japan's technical advance while it was still behind the technology frontier. However, it is reasonable to think that, as Japanese firms have reached the frontier, it has become more important to have technical personnel with highly specialized training.

In some fields, such as software engineering, the shortage of engineers with advanced degrees is so acute that there have been references to a "soft crisis" since the late 1980 s. $^{21}$ Even in the United States, demand for software engineers dramatically outstripped supply in the 1990s - but US immigration law allowed the import of hundreds of thousands of foreign engineers to bridge the gap. ${ }^{22}$

Furthermore, evidence from US industrial patents suggests that, at least in some fields, US firms are increasingly building on academic science in their R\&D efforts. ${ }^{23}$ This also places Japanese firms at a relative disadvantage. US high-tech firms are able to work with, and build on, the research of the world's most celebrated research universities and institutions. Despite important advances over the postwar period, the quantity and quality of

\footnotetext{
${ }^{20}$ See, for example, Okimoto and Saxonhouse (1987).

${ }^{21}$ See Finan and Williams (1992).

${ }^{22}$ We thank Amar Bhide and Ashish Aurora for discussions on the role of immigration in propelling the US high-tech boom of the 1990s.

${ }^{23}$ See Narin et al (1997).
} 
publicly funded research in Japanese universities and research institutes typically lags behind that conducted in the United States. Although the results of this kind of public science are generally published in easily accessible scientific journals, understanding and applying the most recent developments may require a degree of familiarity with, and connection to, that recent science that is harder to come by in Japan than in the United States. ${ }^{24}$

The centralization of R\&D effort in Japan runs counter to the trends in the United States. Over the course of the 1990s, US firms downsized their central R\&D labs and increased emphasis on collaboration with other firms in R\&D and product development. ${ }^{25}$

Some of this collaboration is with high-tech start-up firms, often backed by venture capital, and successful collaboration can lead to acquisition of the start-up by its established partners. For a variety of reasons, there has not been the same kind of venture capital activity in Japan. This means that the domestic set of potential partners is less diverse and, possibly, less technologically dynamic than it is in the United States. The larger Japanese corporate labs seem to have run into the same problems that beset their US counterparts bureaucracy, insularity, and a lack of connection with developments in the market. As we saw in our review of the aggregate statistics, total private sector R\&D spending in the U.S. has continued to grow at a robust rate, but the allocation of that spending across organizational boundaries has changed in a way that has no parallel in Japan - and that may help explain the differences in R\&D productivity.

To its credit, the Japanese government has instituted a number of significant reforms over the course of the 1990s to address some of the perceived problems in the Japanese innovation system and help Japanese firms make the leap from more applied to more basic R\&D. A series of patent reforms, begun in 1988 and culminating in the adoption by the Japanese Supreme Court of the "doctrine of equivalents" in 1998, have dramatically increased the intellectual property rights protections available to inventors under the Japanese patent system. ${ }^{26}$ The government has removed a number of legal restrictions that inhibited the operation of high-tech start-ups. Legal restrictions on the business activities of

\footnotetext{
${ }^{24}$ There is a large literature on the historical role of US universities in fostering technological progress. See, for example, Rosenberg and Nelson (1994)

${ }^{25}$ Several papers in Rosenbloom and Spencer (1996) comment on these trends, including the contribution by Mowery and Teece.

${ }^{26}$ For more details, see Sakakibara and Branstetter (2001).
} 
university professors have been lifted, in an attempt to foster the development of universitylinked start-ups. Finally, there has been a substantial increase in Japanese public funding for R\&D and for graduate education. ${ }^{27}$ Unfortunately, to date these positive policy changes have had little visible impact on research outcomes.

The positive impact of these policy changes has probably been limited by Japan's poor macroeconomic performance, and this brings us to another potential explanation for the slowdown in R\&D productivity - the long-run impact of Japan's lengthy recession. Because $\mathrm{R} \& \mathrm{D}$ at the technological frontier can be a very expensive investment with a highly uncertain payoff, firms under severe financial pressure are often forced to limit their R\&D spending and transfer personnel out of R\&D groups and into operational functions. If Japanese firms are forced to restrain their $R \& D$ investments and pare back the ranks of R\&D personnel year after year, then they inevitably fall behind their international competitors - and the further they fall behind, the harder it may be to catch up. While the nation's most successful firms have been able to maintain large R\&D operations even in the face of Japan's unprecedented recession, the long recession may have left the research operations of others permanently impaired. Similarly, the viability of start-up enterprises is limited in an environment where the overall economy is shrinking or stagnating and equity markets are severely depressed. ${ }^{28}$

A full exploration of the increase in innovative activity in the US is beyond the scope of this paper, but recent research suggests several potentially important casual factors. Clearly the robust economy of the 1990s provided firms with profits to reinvest in R\&D. However, at the same time that $R \& D$ spending has been increasing, $R \& D$ productivity as measured by patents per R\&D dollar has also been rising, so one cannot explain the difference in outcomes by focusing solely on the increase in inputs.

The increase has probably been driven in part by changes in scientific and technological opportunity. Important fundamental scientific breakthroughs in molecular biology, genetics, and genomics have helped fuel a sharp increase in the number of patents granted in fields associated with biotechnology. Likewise, there has been a substantial

\footnotetext{
${ }^{27}$ See Normile (2002) for a summary of these and other recent changes.

${ }^{28}$ There is an interesting contrast here with South Korean firms. Under the impact of the Korean economic crisis of 1997-1998, the R\&D divisions of several Korean firms were spun off as high-tech start-ups. This arrangement kept South Korea's best corporate R\&D personnel employed in research, albeit in a different organizational form. The fraying but still extant Japanese corporate commitment to lifetime employment has kept many researchers employed in their original companies, but not always in a research function.
} 
increase in software patenting. ${ }^{29}$

Corporate patents are increasingly citing scientific papers, suggesting that the link between science and innovation is tighter than in the past. ${ }^{30}$ It is uncertain whether these breakthroughs will continue to generate opportunities for industrial application, but it seems reasonable that the ability of US universities to play a leading role in these scientific breakthroughs has conferred some technological advantage on relatively proximate and better-connected US firms.

However, as Kortum and Lerner $(1999,2000)$ point out, the increase in patenting is not confined to those clusters of technologies that have seen recent fundamental breakthroughs in academic science. Thus, one cannot argue that the increase in US research productivity has been driven entirely by exogenous shifts in technological opportunity. In other words, it is not simply that Japan missed out on the US surge in innovation because it lacked a strong presence in the software industry and the biotech industry, where the positive technological shocks of the 1990s were concentrated. Even in areas of traditional Japanese strength, US firms have been relatively more successful. This point is driven home strongly in Figure 3, which tracks innovation in IT-related patent classes.

Instead, Kortum and Lerner argue that the management of R\&D has undergone an institutional change. Specifically, they assert that a system of small start-up firms financed by venture capital partnerships is more productive than the traditional big corporate $R \& D$ system, and they present evidence that the increase in innovation has been highest where venture capital investment is most concentrated.

Evidence on US patents suggests that, as the large corporate R\&D labs have downsized, knowledge generation by smaller firms and universities have more than compensated. $^{31}$ The early 2000 s downturn in the information-technology sector and largescale bankruptcies of venture-backed high-tech firms suggest that the ultimate power of this institutional innovation to propel increased innovation in the long run may have been overstated, but it is almost certain to have played an important role over the course of the 1990s.

Although the failure of R\&D-intensive Japanese firms to keep pace with their US

\footnotetext{
${ }^{29}$ For recent studies touching on these issues, see Cockburn and Henderson (2000) and Hicks et al (2001).

${ }^{30}$ See, for example, Narin et al (1997) and Branstetter (2001c).

${ }^{31}$ See Hicks et al (2001) and Henderson et al (1998).
} 
counterparts is clearly a cause of concern for the firms themselves, one might question the implications of this for the Japanese economy as a whole. The macroeconomic impact of research success should be evident in measures of total factor productivity (TFP). While estimates of Japanese TFP growth vary widely, depending on the methodology and the level of aggregation at which the analysis was conducted, at least some studies suggest that the contribution of TFP growth to overall Japanese economic growth has been fairly modest in recent decades, even in the 1980s when research productivity was growing rapidly. Does this limit the economic relevance of our study? We would argue that Japan is unlikely to sustain rapid economic growth solely through increases in factor inputs in the medium-tolong run future. Barring radical changes in Japanese immigration policy, Japan's population will age rapidly and actually begin to shrink in coming decades, sharply limiting the growth in labor inputs. Likewise, if anything, Japan over-invested in physical capital in recent years - a point addressed elsewhere in this volume. The prospects of investment-led growth are therefore also limited. The sustainability of a reasonably high rate of macroeconomic growth would thus seem to require growth in TFP. ${ }^{32}$

Of course, one could also question the linkage between TFP growth and domestic R\&D. Certainly, there are sources of TFP growth that are not directly linked to formal research and development activity. Furthermore, the economic impact of slower growth in research productivity at home can be cushioned by importing foreign-invented high-tech products. In addition, Japanese investors could realize some of the returns from foreign innovation by investing overseas. However, it is still likely to be the case that both Japan and the world as a whole will grow more slowly if Japanese R\&D productivity continues to stagnate. Furthermore, modern growth theory has suggested a range of conditions under which foreign innovation can be an imperfect substitute for domestic innovation. ${ }^{33}$ If these conditions hold, the implications of Japan's R\&D productivity slowdown for domestic economic growth could be even more severe. ${ }^{34}$

\footnotetext{
${ }^{32}$ We thank Jenny Corbett for discussions on these issues.

${ }^{33}$ See Grossman and Helpman (1991) and Feenstra (1996).

${ }^{34}$ We acknowledge that our study focuses on a relatively narrow range of firms and industries that collectively constitute a relatively small part of the Japanese economy. However, these are precisely the firms and industries where formal R\&D activity is most highly concentrated. Given that our objective is really to assess the changing productivity of formal R\&D activity - rather than explain overall performance of the macroeconomy -- we believe this focus is appropriate.
} 


\section{$4 \quad$ Tapping US Technology}

In the face of a perceived relative decline in R\&D productivity, Japanese R\&D managers have not stood still. While we eventually hope to explore all of the aspects of the Japanese industrial R\&D restructuring outlined in the previous section as part of a long-term research project, here we focus on the international dimension of Japanese firms' R\&D restructuring. In doing so, we endeavor to answer two questions. First, how and to what extent are Japanese firms seeking to obtain useful technological information from US sources? Second, is this strategy working? In other words, have Japanese firms that have made the effort to tap US technology networks benefited in terms of raising their R\&D productivity? Drawing on recent research by one of the authors, we seek to shed light on these questions in this section.

As much prior research has documented, Japanese firms have historically been enthusiastic licensees of US technology. However, the concept of tapping into US technology networks that we attempt to measure here is more than passive implementation of technology developed by another firm. Rather, it is the incorporation of ideas developed outside the firm into the firm's own R\&D operation. It is much more pro-active than simple licensing, and an important method by which this happens is the formation of technology alliances with US firms. Japanese firms' overseas R\&D facilities obviously also play an important role in these firms' efforts to learn from US technological developments, but in this section, we focus on the impact of technology alliances. ${ }^{35}$

\subsection{Research Alliances}

\footnotetext{
${ }^{35}$ For evidence on the effectiveness with which Japanese firms have used their FDI in the US, including their US R\&D facilities, to tap into technology networks, see Branstetter (2000). For more general studies on the scale of overseas R\&D by Japanese firms, see Belderbos (2001) and Odagiri and Yasuda (1997).
} 
Japanese firms have been aggressive about forming technology-sharing and technologydevelopment alliances with US firms. Several data sources track these over time, identifying the Japanese and US partners. The source used here, the Securities Data Corporation (SDC) alliance database, uses contemporary press accounts to track corporate alliances, of which the "technology" alliances that are the focus of this section are a subset. ${ }^{36}$

\subsection{Promoting Knowledge Flows}

Do alliances with US firms and universities promote flows of knowledge to Japanese firms? We assess this using data on the citations to prior US inventions found in the US patents of Japanese firms. We are careful to exclude all Japanese-invented US patents from this set of "American" inventions. Using an empirical methodology developed in Branstetter (2000), we presume that the flow of patent citations is proportional to the flow of knowledge. ${ }^{37}$

Let $C_{J i t}$ be the number of citations made by the patent applications Japanese firm $i$ filed in year $t$ to the cumulated stock of "indigenous" US-invented patents granted as of year $t$. Note that the US Patent and Trademark Office makes available data only on patent applications that are eventually granted. In this paper, patents are dated by year of application rather than year of grant, because it takes on average two years - sometimes much longer - to grant a patent.

We can write the expectation of $C_{J i t}$ as a function of several other observables

$$
E\left[C_{J i t}\right]=\left(N_{\text {Jit }}\right)^{\beta_{1}}\left(N_{A t}\right)^{\beta_{2}}\left[e^{\beta_{3} \text { Alliance }_{i t}}\right]\left[e^{\beta_{4} P R O X_{i}}\right] R_{i t}^{\beta_{6}} \alpha_{i} \alpha_{t}
$$

Let $E$ be the expectations operator. Here $\mathrm{E}\left[C_{j i t}\right]$ is a function of the number of patents Japanese firm $i$ has taken out in the US in year $t\left(N_{J i t}\right)$, the number of potentially cited indigenous US patents which exist as of year $t\left(N_{A t}\right)$, the level of firm $i$ 's alliance activity with US firms in year $t$ (Alliance ${ }_{i t}$ ), and the extent to which firm $i$ is at a point in the technology space which is "densely populated" by other indigenous US patents $\left(P R O X_{i}\right)$.

Some Japanese firms might cite US patents more frequently simply because they

\footnotetext{
${ }^{36}$ The authors subsequently began using an even more comprehensive database, the CATI database developed by John Hagedoorn at the University of Maastricht, to explore the impact of alliances more thoroughly.

${ }^{37}$ This framework builds on the methodology of Jaffe and Trajtenberg (1996) and uses the citations data described in Hall, Jaffe, and Trajtenberg (2001). The exposition of the empirical framework closely follows Branstetter (2000) quite closely.
} 
happen to be working on technologies in which a large number of indigenous US inventors are active. If one wishes to control for this "technological proximity," one could obtain a measure of a firm's location in "technology space" by measuring the distribution of its R\&D effort across various technological fields. Let firm $i$ 's R\&D program be described by the vector $F$, where

$F_{i}=\left(f_{1}, \ldots, f_{k}\right)$

and each of the $k$ elements of $F$ represent the firm's research resources and expertise in the $k$ th technological category. These are constructed by aggregating the hundreds of patent classes in the US Patent and Trademark Office system into 50 distinct areas. We then count the number of patents taken out by firm $i$ in each of the categories over the full length of the sample period.

From the number of patents taken out in different categories, we can infer what the distribution of R\&D investment and technological expertise across different technical fields has been. In the same way, we can also compute a vector of location in technology space for the aggregate of all US inventors, treating them as though they belonged to a single giant enterprise, and denoting that $F_{U S}$. This suggests that $P R O X_{i}$ might be measured as

$$
P R O X_{i}=\frac{F_{i} F_{U S}^{\prime}}{\left[\left(F_{i} F_{i}^{\prime}\right)\left(F_{U S} F_{U S}^{\prime}\right)\right]^{1 / 2}}
$$

This is a technological proximity coefficient in the spirit of Jaffe (1986).

One may also wish to allow citations to be influenced by the firms' R\&D spending $\left(R_{i t}\right)$ and by vectors of multiplicative "fixed effects" associated with the citing firm $\left(\alpha_{i}\right)$ and the (application) year in which the citation takes place $\left(\alpha_{t}\right)$. Including these fixed effects actually simplifies the equation, provided one is willing to make some assumptions. The stock of cumulated potentially citable "indigenous" US patents will be the same for all Japanese citing firms in each year, so that the $N_{A t}$ terms are effectively absorbed into the time dummies. One may also want to assume that a firm's location in technology space relative to aggregate US inventive activity is relatively fixed over time. In that case, the effect of the $P R O X$ measure is absorbed into the firm fixed effects in a standard fixed effects regression. Industry effects also will be absorbed into the firm effects, because firms in the sample do not change their primary industry affiliation over time.

The assumption that the technological proximity of a Japanese firm to US inventive 
activity stays fixed over a long period is a strong one. The data permit us to allow this proximity measure to vary within firms over time, although we lack sufficiently rich patent data to do this for all firms or all years. The specification suggested by this line of thinking is

$$
c_{J i t}=\beta_{0}+\beta_{1} p_{i t}+\beta_{2} r_{i t}+\beta_{3} \text { Alliance }_{i t}+\beta_{4} P R O X_{i t}+\sum \alpha_{t} T_{t}+\alpha_{i}+\varepsilon_{i t}
$$

The focus of interest is on $\beta_{3}$. Do firms that engage in more frequent technology alliances and R\&D joint ventures with US experience an increased tendency to cite US patents? A positive, significant coefficients would suggest the answer is yes.

There is a data problem in that the dependent variable for a nontrivial number of observations is 0 . We deal with this by estimating a fixed effects negative binomial version of equation (9). Results are given in Table 3.

We see clearly that alliances have a positive, statistically significant impact on the measured flow of technological knowledge from US to Japanese firms when they are entered separately into the regression. Although the coefficient is small in magnitude, one must recall that it gives the increase in knowledge flows associated with the establishment of an additional alliance. Because some firms in our data set went from zero alliances to several dozen, the cumulative effect implied by the regression coefficients is quite substantial.

Our conversations with Japanese R\&D managers suggest an important complementarity between overseas R\&D facilities and R\&D alliances. Often, overseas R\&D centers are used as a base from which to search out alliance partners and, in many cases, the site of R\&D centers is selected with current or potential alliance partners in mind. In future work, we hope to explore this apparent complementarity further.

\subsection{Putting Knowledge Flows to Work}

The finding that the establishment of research alliances enhances knowledge flows is of limited interest unless firms that receive greater knowledge flows from the United States are able to translate these flows into greater innovative productivity. Firmly establishing such a causal linkage is difficult, but in the Table 4 we present evidence that is at least consistent with such a linkage.

The first column reports the results of a fixed effects negative binomial regression. In this case, the dependent variable is our citation-adjusted measure of US patent output. We regress this on firm-level R\&D spending and a firm-specific time-varying measure of 
knowledge flows from the United States.

This measure is the count of citations to US patents - the dependent variable from our previous set of regression results. We see clearly that US knowledge flows are positively associated with higher quality patent output, and that this association is robust to the inclusion of a control for patent counts. ${ }^{38}$ The coefficient is very small, but the statistical interpretation of this coefficient is the increase in patent quality associated with an additional citation. Because some firms make hundreds of such citations in a single year's cohort of patent applications, the cumulative effects of a substantial increase in such citations could be quite substantial.

This point is demonstrated by the results in the second column. The measure of knowledge flow used in this column is a simple dummy variable equal to one if the firm in question receives higher than the median level of citations over the sample period. A random effects negative binomial regression shows that this variable is highly significant and large in magnitude, suggesting that there is a strong correlation in the cross section between high levels of knowledge flow and high levels of quality-adjusted patent output. Frequently citing firms generate patents that are nearly $90 \%$ "better," as measured by their ex-post citations. We cannot interpret this as strong causal evidence of a linkage between knowledge flows from the United States and invention quality, because there are likely to be important unmeasured differences in the research quality of firms which may be correlated with the frequency with which they cite US patents. Nevertheless, these results offer large sample statistical evidence consistent with the view expressed by our interviewees that tapping US technology networks can be a useful component of an R\&D reform strategy.

\section{Conclusion}

As the 1980s ended, Japanese firms were held up as exemplars of strength in technological innovation. As the 21 st century begins, leaders in government and industry are calling for a reform of the national innovation system in order to raise the long-run sustainable growth rate of the Japanese economy. This chapter has demonstrated that there are reasonable

\footnotetext{
${ }^{38}$ The obvious relationship between counts of citations to prior US patents and the number of successful Japanese patent applications requires the use of this control. This implies that our innovative output measure is, in effect, measuring the average quality of patents in a given cohort.
} 
grounds for concern about the relative performance of Japanese manufacturing firms in technology-intensive industries.

To answer the question posed by our title, we do not find strong evidence that Japanese innovative capacity has actually declined. However, that capacity has failed to grow at the rate of the 1980s. As a result, US and worldwide patent statistics suggest that Japanese firms in a number of sectors have fallen behind their US counterparts, even in areas where Japanese firms were formerly quite strong and rapidly converging on US levels of inventive output.

Microeconometric analysis suggests that this decline in relative performance cannot be entirely ascribed to a relative reduction in $\mathrm{R} \& \mathrm{D}$ inputs, though such a relative reduction has occurred. We find evidence consistent with the view that, outside the electronics sector, R\&D productivity growth has stagnated in the $1990 \mathrm{~s}$ - perhaps even declined. This view is strongly reflected in the US patent data, and the results are robust to an adjustment for the quality of individual US patents.

Anecdotal evidence from $R \& D$ manager interviews is strongly consistent with a slowdown or decline in Japanese R\&D productivity relative to the firms' US competitors and relative to their own experience in the 1980s. These interviews suggest that the structural shift in Japanese R\&D over the course of the late 1980s and 1990s may have contributed to the observed stagnation in $R \& D$ productivity growth. Japanese firms are not well equipped for more fundamental research due to the educational backgrounds of their engineers, the weakness of Japanese academic science, and the lack of a robust domestic venture capital industry.

Firms are taking steps to increase the efficiency of their R\&D operations, and one key strategy adopted to varying degrees by all interviewed firms includes an increased emphasis on tapping US technology networks. In the absence of strong domestic institutions, Japanese firms are creating ties to US universities, start-ups, and established firms. Our microeconometric assessment of the impact of one of the steps taken to accomplish this strategic goal finds that the formation of technology-sharing alliances with US firms have a positive impact on knowledge flow from US to Japanese firms. Finally, we show that increased international knowledge flows are strongly correlated with higher levels of innovative performance, at least in the firm cross-section. Therefore, Japanese firms that have most successfully tapped into US technology networks enjoy a relatively higher level of R\&D productivity. 
In terms of public policy implications, as we have already noted, the government has taken a number of steps to improve Japan's academic science base and enhance the business environment for start-ups. However, these policy changes are unlikely to have substantial positive impact until Japan's overall macroeconomic situation improves. While the downturn in innovative activity is not to blame for Japan's poor macroeconomic performance, continued stagnation of the Japanese economy could have long-lasting negative effects on the research operations of Japanese firms. Thus, the most effective step the government could take in the short run to enhance Japan's innovative performance is to revive economic growth. A discussion of macroeconomic policies to accomplish that is beyond the scope of this paper, but we strongly concur with those who advocate the adoption of a positive inflation target by the Bank of Japan, tax cuts to stimulate growth, and a careful recapitalization of the banking system.

Like most empirical research projects, this essay leaves us with a number of unanswered (or only partially answered) questions which we hope to pursue in further work. First, do our tentative explanations for the observed decline in the growth of Japanese R\&D productivity stand up to more rigorous empirical testing? Our current hypothesis suggests a negative relationship between a shift to more basic research and research productivity that could be explored more thoroughly. Second, have the other dimensions of R\&D reform mentioned in the third section been enhancing research productivity? Our next-round examination of $R \& D$ restructuring by Japanese firms will consider all aspects of the process. We believe that this more comprehensive study could shed useful light on the extent of the restructuring, the degree to which different components have had positive effects on research productivity, and the role that public policy could play in enhancing the evolution of the Japanese innovation system.

Our interviews strongly suggested that the move toward partial outsourcing of R\&D is a conscious imitation of a shift that is already well underway in the United States. A Japanese perspective on the global process of vertical disintegration of R\&D may offer useful lessons on this process for the rest of the world. 


\section{References}

Arison, Thomas, C. Fred Bergsten, Edward Graham, and Martha C. Harris, editors, 1992, Japan's Growing Technological Capability: Implications for the U.S. Economy, Washington DC: National Academy Press.

Belderbos, Rene, 2001, “Overseas Innovations by Japanese Firms: An Analysis of Patent and Subsidiary Data," Research Policy 30: 313-332.

Branstetter, Lee and Mariko Sakakibara, 1998, "Japanese Research Consortia: A Microeconometric Analysis of Industrial Policy," Journal of Industrial Economics, 46(2): 207-33.

Branstetter, Lee, 2000, “Is Foreign Direct Investment a Channel of Knowledge Spillovers? Evidence from Japan's FDI in the United States," NBER Working Paper 8015.

Branstetter, Lee, 2001a, “Are Knowledge Spillovers International or Intranational in Scope? Microeconometric Evidence from the U.S. and Japan," Journal of International Economics, 53: 53-79.

Branstetter, Lee, 2001b, “The Roles of FDI and Interfirm R\&D Alliances in International Knowledge Spillovers: Evidence from Japanese Multinational Firms,” working paper, Columbia Business School.

Branstetter, Lee, 2001c, "Measuring the Link between Academic Science and Industrial Innovation - The Case of California's Research Universities," working paper, Columbia Business School.

Clark, Kim and Takahiro Fujimoto, 1991, Product Development Performance, Boston: Harvard Business School Press. 
Cockburn, Iain and Rebecca Henderson, 2000, "Publicly Funded Science and the Productivity of the Pharmaceutical Industry," in Adam Jaffe, Joshua Lerner, and Scott Stern, editors, Innovation Policy and the Economy, Volume 1, Cambridge, MA: MIT Press.

Cohen, Wesley, Akira Goto, Akiya Nagata, Richard Nelson, and John Walsh, 1998, "R\&D Spillovers, Patents, and the Incentives to Innovate in Japan and the United States," working paper, Carnegie Mellon University.

Feenstra, Robert, 1996, "Trade and Uneven Growth," Journal of Development Economics, 49: 229-56.

Finan, William and Carl Williams, 1992, "Implications of Japan's 'Soft Crisis': Forcing New Directions for Japanese Electronics Companies," in Arison, Thomas, C. Fred Bergsten, Edward Graham, and Martha C. Harris, editors, 1992, Japan's Growing Technological Capability: Implications for the U.S. Economy, Washington DC: National Academy Press.

Gijutsu Yōran 2000 [Indicators of Science and Technology], published by the Science and Technology Policy Bureau of the Science and Technology Agency, Government of Japan.

Goto, Akira, 1993, Nihon no Gijutsu Kakushin to Sangyō Soshiki, Tokyo: University of Tokyo Press.

Goto, Akira, 1997, "Introduction," in Innovation in Japan, Akira Goto and Hiroyuki Odagiri, editors, Oxford: Clarendon Press.

Goto, Akira and Akiya Nagata, 1997, Technological Opportunities and Appropriating the Returns from Innovation: Comparison of Survey Results from Japan and the U.S., NISTEP Report 48.

Grossman, Gene and Elhanan Helpman, 1991, Innovation and Growth in the Global Economy, Cambridge: The MIT Press. 
Hausman, Jerry, Bronwyn Hall, and Zvi Griliches, 1984, "Econometric Models for Count Data with an Application to the Patents - R\&D Relationship," Econometrica, 52(4): 909-38.

Hall, Bronwyn, Adam Jaffe, and Manuel Trajtenberg, 2001, "The NBER Patent Citation Data File: Lessons, Insights, and Methodological Tools” NBER Working Paper 8498.

Henderson, Rebecca, Adam Jaffe, and Manuel Trajtenberg, 1998, "Universities as a Source of Commercial Technology: A Detailed Analysis of University Patenting, 1965-1988," Review of Economics and Statistics, 80(1): 119-27.

Hicks, Diana, Tony Breitzman, Dominic Olivastro, and Kimberly Hamilton, 2001, “The Changing Composition of Innovative Activity in the U.S. - A Portrait Based on Patent Analysis," Research Policy, 30: 681-703.

Jaffe, Adam, 1986, "Technological Opportunity and the Spillover of R\&D: Evidence from Firms' Patents, Profits, and Market Value," American Economic Review, 76: 984-1001.

Jaffe, Adam and Manuel Trajtenberg, 1996, "Flows of Knowledge Spillovers from Universities and Federal Labs: Modeling the Flow of Patent Citations Across Institutional and Geographic Boundaries," NBER Working Paper 5712.

Kortum, Samuel and Joshua Lerner, 1999, "What is Behind the Recent Surge in Patenting?" Research Policy, 28: 1-22.

Kortum, Samuel and Joshua Lerner, 2000, "Assessing the Contribution of Venture Capital to Innovation," Rand Journal of Economics, 31: 674-92.

Mansfield, Edwin, 1988, "Industrial R\&D in Japan and the United States: A Comparative Study," American Economic Review Papers and Proceedings, 78(2): 223-28.

National Academy of Engineering, 1987, Strengthening U.S. Engineering through International Cooperation: Some Recommendations for Action, Washington DC: National Academy Press. 
Narin, Fran, Kimberly Hamilton, and Dominic Olivastro, 1997, "The Increasing Linkage Between U.S. Technology and Public Science," Research Policy, 26: 317-330.

Normile, Dennis, 2002, “Japan Asks Why More Yen Don’t Yield More Products,” Science 296: 1230-1231.

Odagiri, Hiroyuki and Hideto Yasuda, 1997, "Overseas R\&D Activities of Japanese Firms," in Innovation in Japan, Akira Goto and Hiroyuki Odagiri, editors, Clarendon Press, Oxford.

Okimoto, Daniel and Gary Saxonhouse, 1987, "Technology and the Future of the Economy" in The Political Economy of Japan, Volume 1: The Domestic Transformation, Kozo Yamamura and Yasukichi Yasuba, editors, Stanford CA: Stanford University Press.

Posen, Adam, 1998, Restoring Japan's Economic Growth, Washington DC: Institute for International Economics.

Posen, Adam, 2001, "Unchanging Innovation and Changing Economic Performance in Japan," in Richard Nelson, Benn Steil, and David Victor, editors, Technological Innovation and National Economic Performance, Princeton, NJ: Princeton University Press.

Rosenberg, Nathan and Richard Nelson, 1994, "American Universities and Technical Advance in Industry," Research Policy, 23: 323-48.

Rosenbloom, Richard and William Spencer, 1996, Engines of Innovation: U.S. Industrial Research at the End of an Era, Boston: Harvard Business School Press.

Sakakibara, Mariko and Lee Branstetter, 2001, "Do Stronger Patents Induce More Innovation? Evidence from the Japanese 1988 Patent Reforms," RAND Journal of Economics, 32(1): 77-100. 
Wakasugi, Ryuhei and Fumihiko Koyata, 1997, "R\&D, Firm Size and Innovation Outputs: Are Japanese Firms Efficient in Product Development?" the Journal of Product Innovation Management, 14: 383-92. 


\section{Figure 1}

\section{Private Sector R\&D Spending in the U.S. and Japan, 1985-1999}

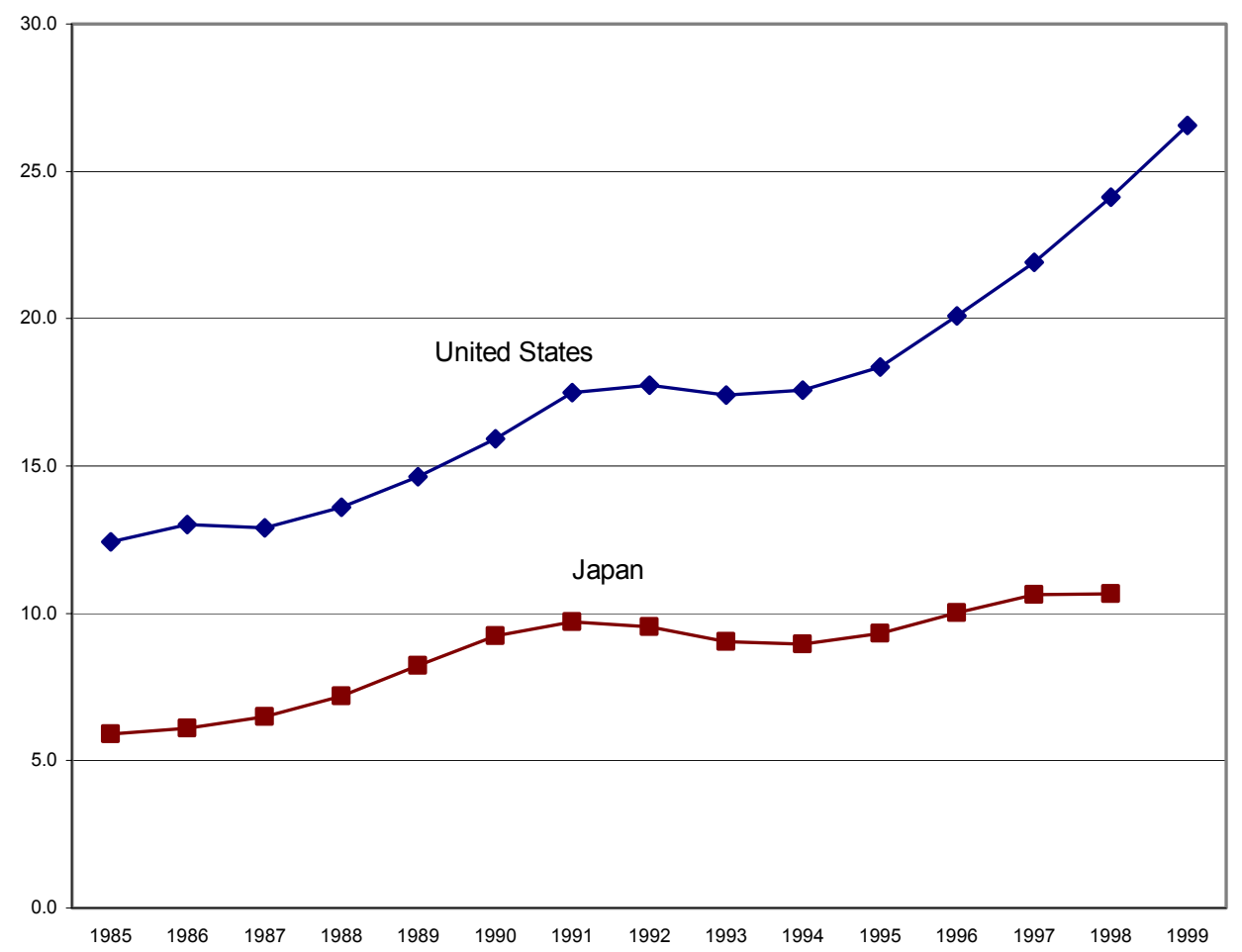

The y axis is real private sector R\&D spending converted into trillions of yen using OECD purchasing power parity exchange rates for each year.

Source: Gijutsu Yōran 2000. 


\section{Figure 2}

Counts of patents granted by the U.S. Patent and Trademark Office, 1980-1999

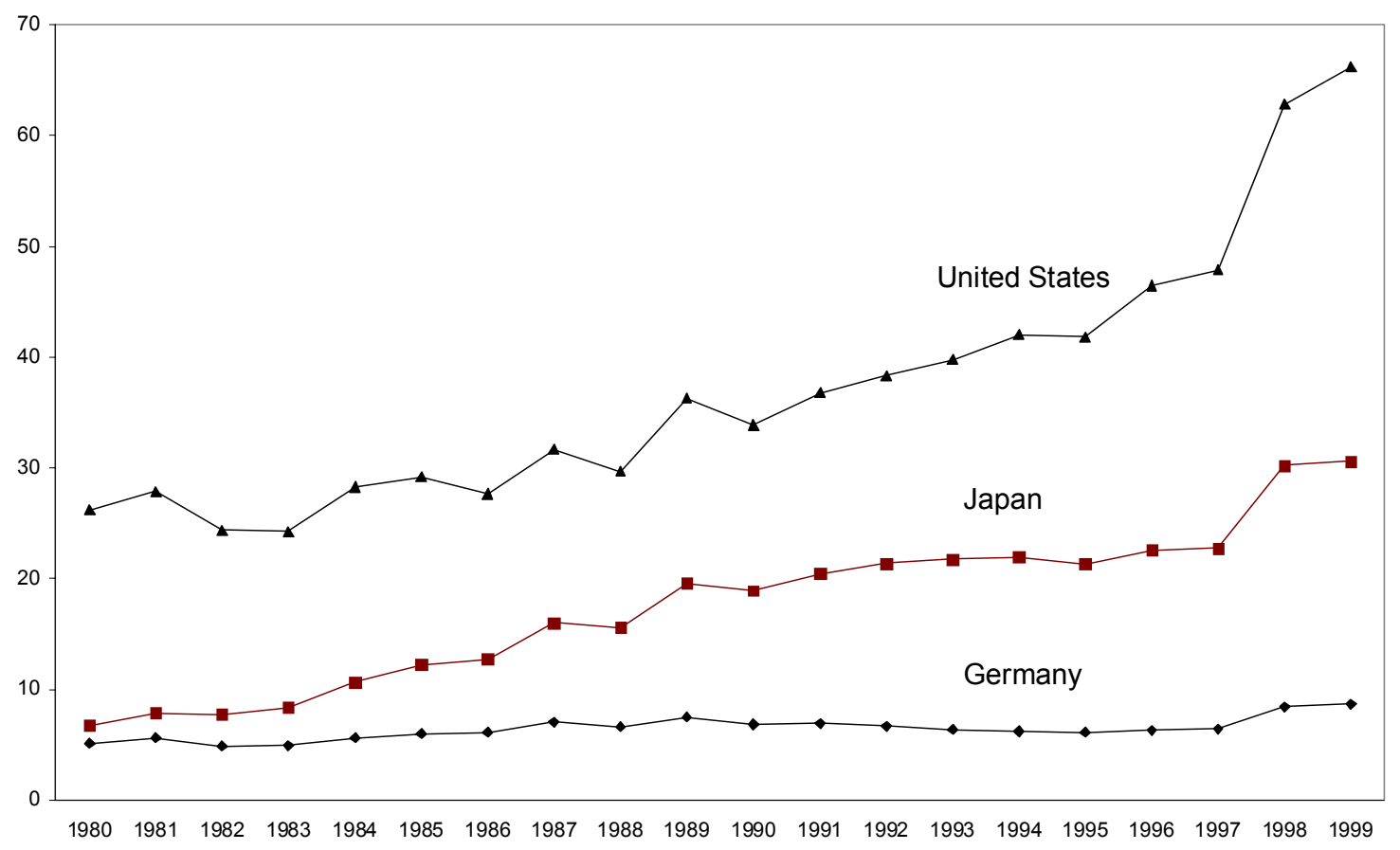

(Units of the vertical axis are thousands of patents)

The Figure shows a dramatic jump in patenting after 1997. This may relate to a change in US patent law regarding the length of patents, as pointed out by Hicks et al (2001). The law included a clause allowing patents filed before 8 June 1995 to receive certain procedural advantages. The expiration of these patents could be set either 17 years from the grant date or 20 years from the priority date, whichever was later. Patent attorneys evidently encouraged their clients to speed up their patent filing in order to meet this deadline. Because of the delays typical in the patent review procedure, an increase in patents granted would not be obvious in the data until two to three years after the deadline.

Source: Authors' calculations based on the NBER Patent Database. 


\section{Figure 3}

Counts of IT patents granted by the U.S. Patent and Trademark Office, 1980-1999

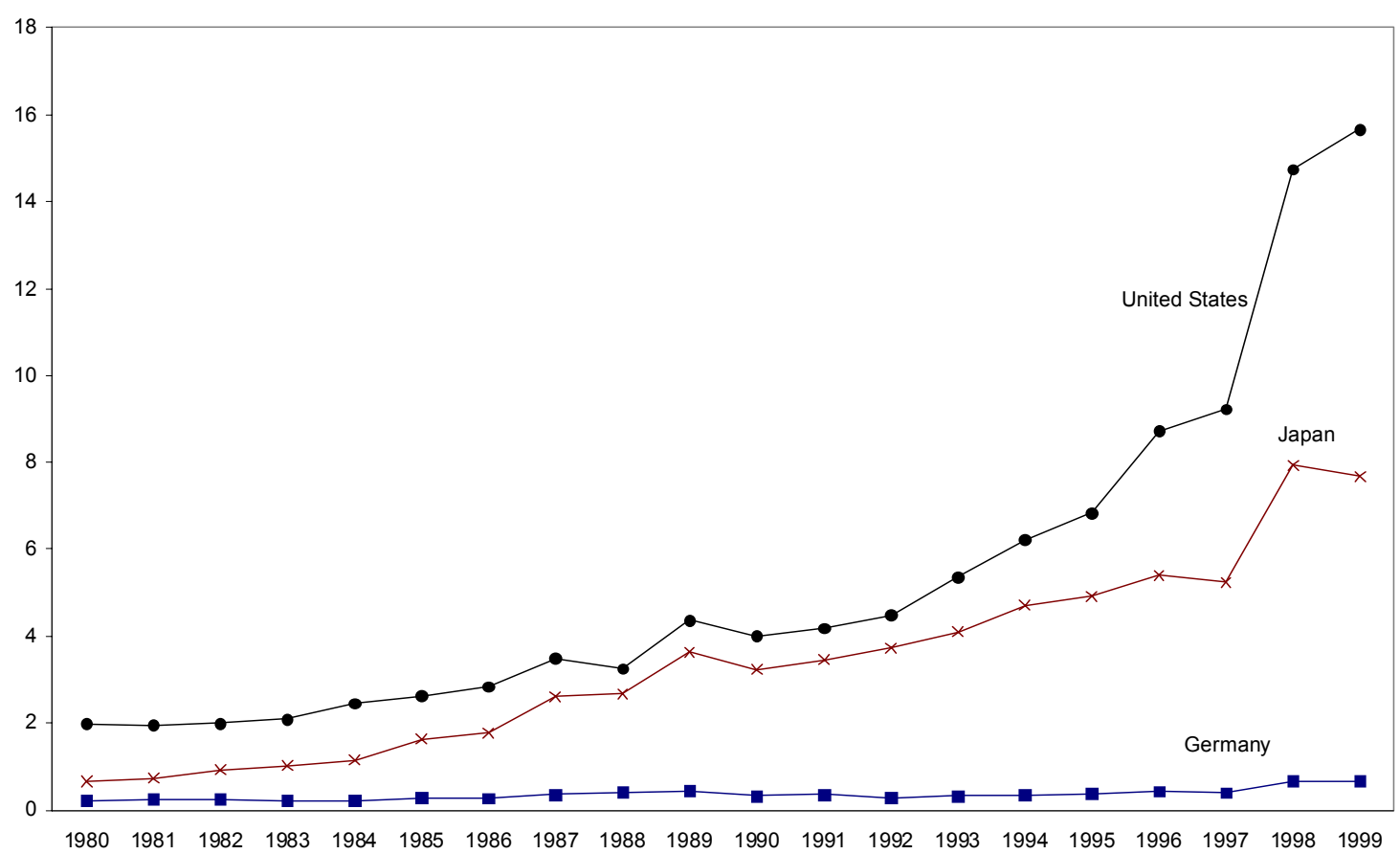

(Units of vertical axis are thousands of patents)

See note to Figure 2.

Source: Authors' calculations based on the NBER Patent Database. 


\section{Figure 4}

Patent Applications by Nationality of Inventor, 1987-1997

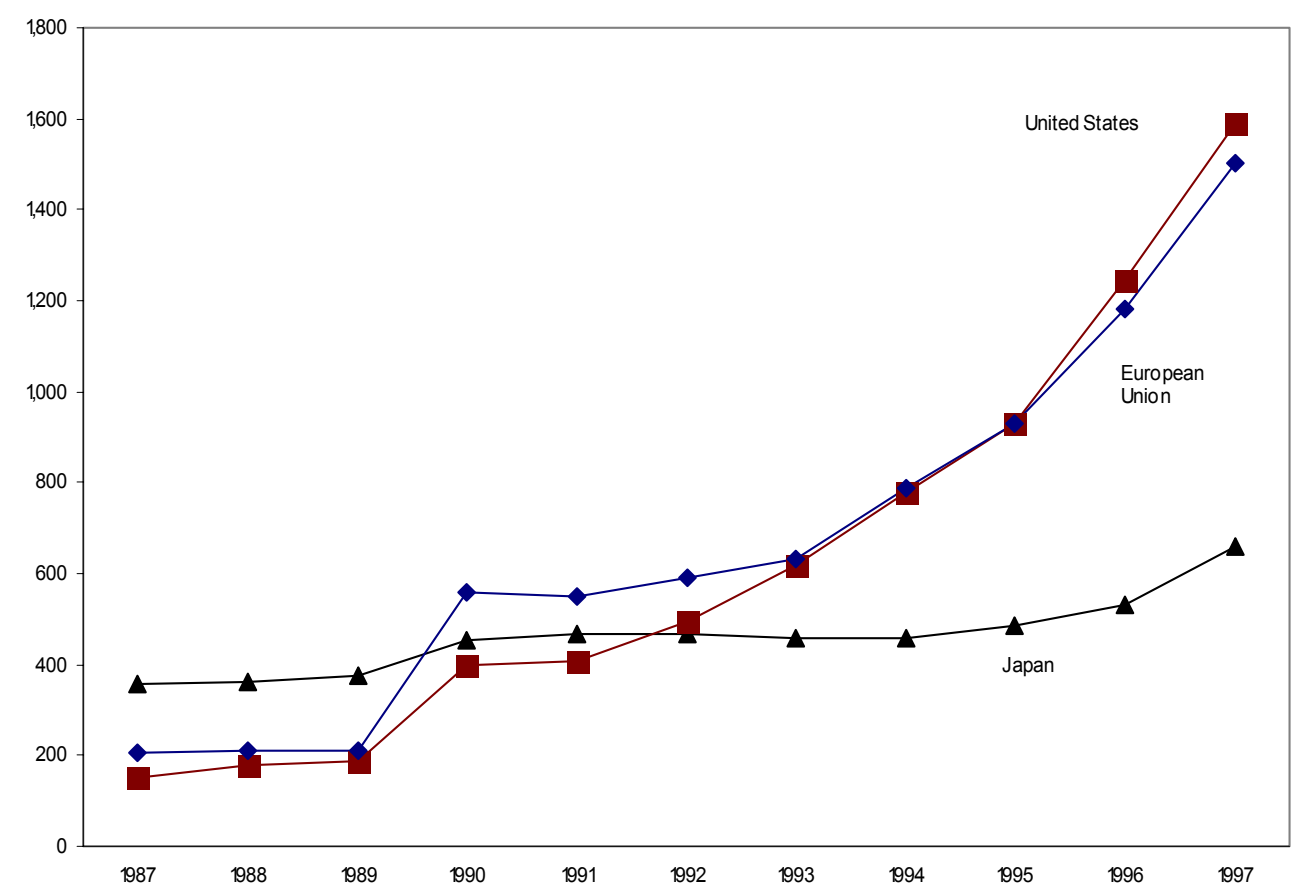

(Units of the vertical axis are thousands of patents)

This measures patent applications generated by inventors in the indicated country and submitted world-wide.

Source: Gijutsu Yōran 2000. 
Table 1

\section{Japanese R\&D Productivity Trends}

Fixed effects negative binomial regression models $\mathrm{Obs}=2,726$

\begin{tabular}{|c|c|c|}
\hline Variable & Patent counts & $\begin{array}{l}\text { Citation-adjusted patent } \\
\text { counts }\end{array}$ \\
\hline new_lrnd & $\begin{array}{c}0.294 \\
(0.0206)\end{array}$ & $\begin{array}{c}0.385 \\
(0.0190)\end{array}$ \\
\hline 82 & -0.0501 & -0.0706 \\
\hline 83 & $\begin{array}{c}(0.100) \\
-0.0776 \\
(0.0940)\end{array}$ & $\begin{array}{c}(0.109) \\
-0.0714 \\
(0.101)\end{array}$ \\
\hline 84 & $\begin{array}{c}0.0751 \\
(0.0907)\end{array}$ & $\begin{array}{c}0.146 \\
(0.0972)\end{array}$ \\
\hline 85 & $\begin{array}{c}0.131 \\
(0.0894)\end{array}$ & $\begin{array}{c}0.167 \\
(0.0962)\end{array}$ \\
\hline 86 & $\begin{array}{c}0.208 \\
(0.0873)\end{array}$ & $\begin{array}{c}0.259 \\
(0.0936)\end{array}$ \\
\hline 87 & $\begin{array}{c}0.261 \\
(0.0863)\end{array}$ & $\begin{array}{c}0.328 \\
(0.0923)\end{array}$ \\
\hline 88 & $\begin{array}{c}0.403 \\
0.0844\end{array}$ & $\begin{array}{c}0.431 \\
(0.0907)\end{array}$ \\
\hline 89 & $\begin{array}{c}0.553 \\
(0.0830)\end{array}$ & $\begin{array}{c}0.586 \\
(0.0891)\end{array}$ \\
\hline 90 & $\begin{array}{c}0.541 \\
(0.0832)\end{array}$ & $\begin{array}{c}0.552 \\
(0.0894)\end{array}$ \\
\hline 91 & $\begin{array}{c}0.552 \\
(0.0830)\end{array}$ & $\begin{array}{c}0.535 \\
(0.0890)\end{array}$ \\
\hline 92 & $\begin{array}{c}0.486 \\
(0.0836)\end{array}$ & $\begin{array}{c}0.473 \\
(0.0896)\end{array}$ \\
\hline 93 & $\begin{array}{c}0.513 \\
(0.0840)\end{array}$ & $\begin{array}{c}0.516 \\
(0.0889)\end{array}$ \\
\hline 94 & $\begin{array}{c}0.559 \\
(0.0827)\end{array}$ & $\begin{array}{c}0.552 \\
(0.0889)\end{array}$ \\
\hline 95 & $\begin{array}{c}0.609 \\
(0.0827)\end{array}$ & $\begin{array}{c}0.396 \\
(0.0908)\end{array}$ \\
\hline 96 & $\begin{array}{c}0.571 \\
(0.0841)\end{array}$ & $\begin{array}{c}0.0720 \\
(0.0958)\end{array}$ \\
\hline 97 & $\begin{array}{c}0.463 \\
(0.0849)\end{array}$ & $\begin{array}{c}-0.193 \\
(0.0988)\end{array}$ \\
\hline _cons & $\begin{array}{l}-0.515 \\
(0.115)\end{array}$ & $\begin{array}{c}-1.32 \\
(0.109)\end{array}$ \\
\hline Log Likelihood & $-8,173.9$ & $-10,179.2$ \\
\hline
\end{tabular}




\section{Figure 5}

Trends in Japanese R\&D Productivity, 1982-1997

Regression Results from Table 1, Column 1

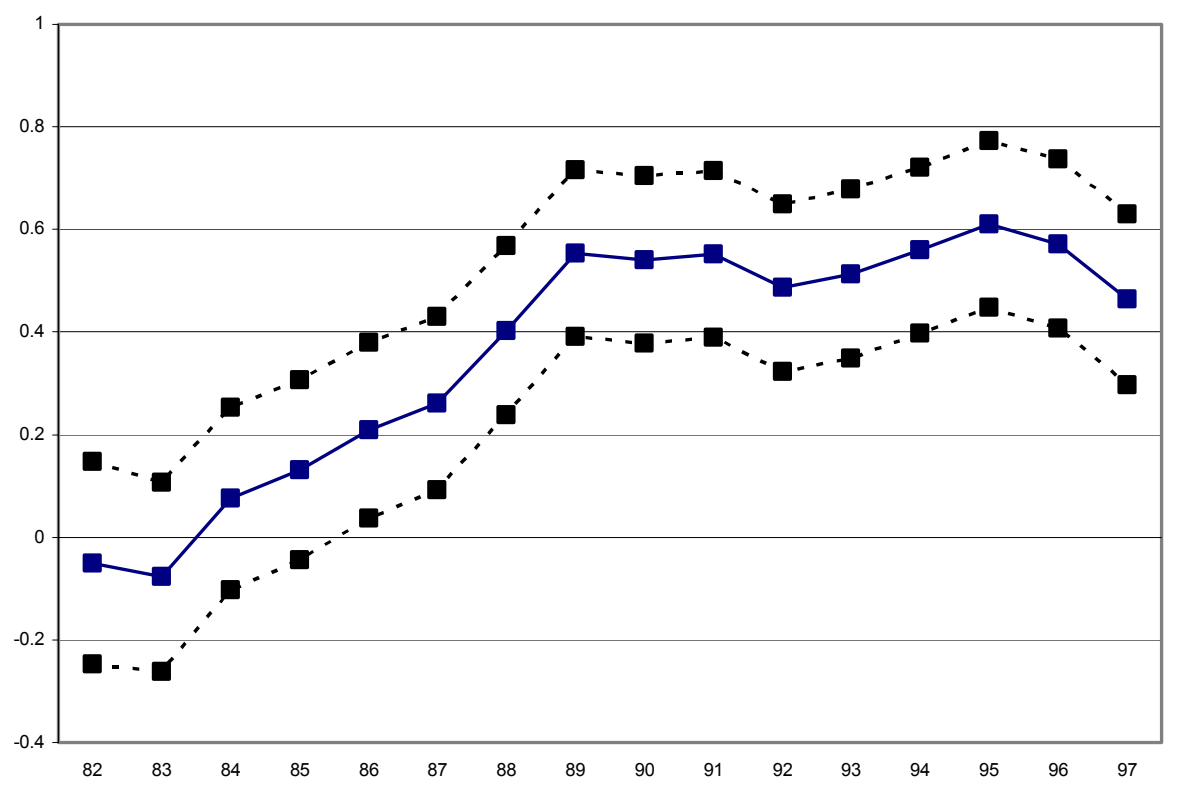

Regression results from Table 1, Column 1

Year dummy coefficients from Table 1, with associated 95\% confidence bounds. 


\section{Figure 6}

Trends in Japanese R\&D Productivity

Regression results from Table 1, Column 2

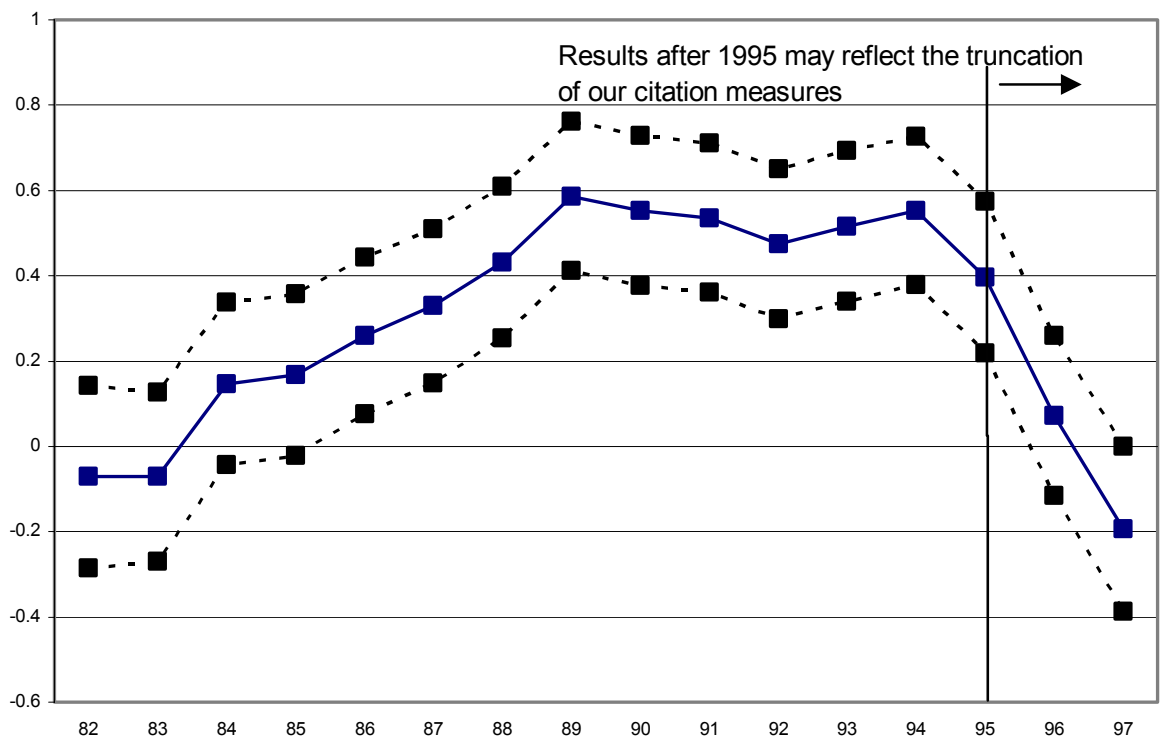

Regression results from Table 1, Column 2

Year dummy coefficients from Table 1, with associated 95\% confidence bounds.

The sharp decline in measured productivity in the last years of our sample is an artifact of our data. Detailed studies of patent citations show that it takes several years for citations to a particular invention to peak (see Jaffe and Trajtenberg 1996). A patent applied for in 1996 would not be granted, on average, until 1997 or 1998 - possibly even later. Thus, we picking up less than four years' of citations. For this reason, coefficients on year dummies for years later than 1995 should be viewed with caution. Nevertheless, we see this graph as providing confirming evidence of a stagnation of R\&D productivity growth in the $1990 \mathrm{~s}$. 


\section{Figure 7}

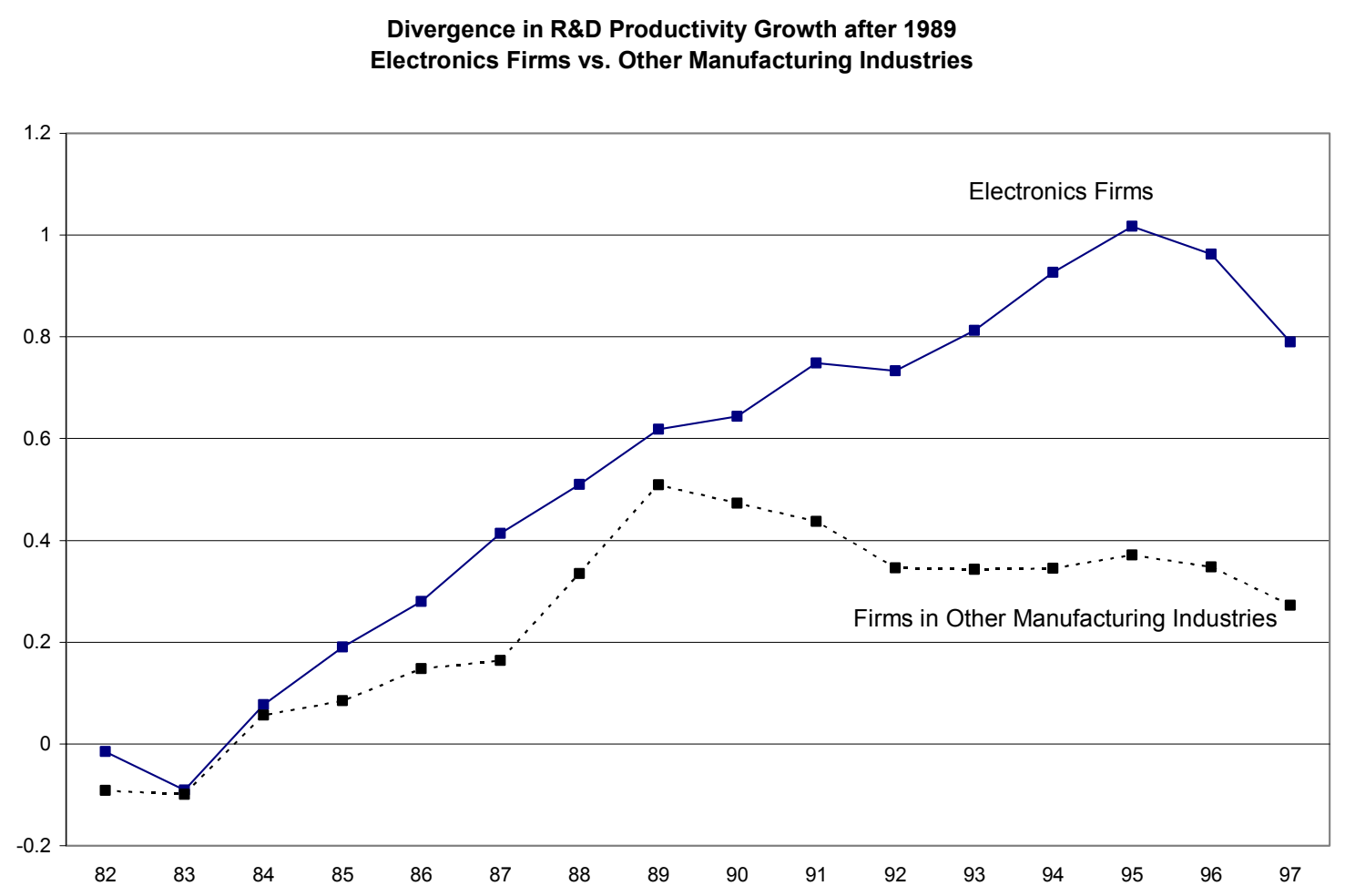

The measured decline after 1995 could reflect, in part, the "truncation" problem in our data referred to in Figure 6. Not all patents applied for in 1996 and 1997 were granted by 1999.

Source: Authors' regression results. 
Table 2 Japanese R\&D Productivity Trends

Fixed effects negative binomial regression models using Japanese patent application data

\begin{tabular}{|c|c|c|c|}
\hline Variable & Patent counts & $\begin{array}{l}\text { Patent counts } \\
\text { (electronics) }\end{array}$ & $\begin{array}{c}\text { Patent counts } \\
\text { (other manufacturing) }\end{array}$ \\
\hline \multirow[t]{2}{*}{ New_lrnd } & 0.119 & 0.0470 & 0.186 \\
\hline & $(0.0147)$ & $(0.0236)$ & $(0.0212)$ \\
\hline \multirow{2}{*}{82} & 0.140 & 0.216 & 0.109 \\
\hline & $(0.0677)$ & $(0.137)$ & $(0.0748)$ \\
\hline \multirow[t]{2}{*}{83} & 0.201 & 0.214 & 0.210 \\
\hline & $(0.0615)$ & $(0.124)$ & $(0.0682)$ \\
\hline \multirow[t]{2}{*}{84} & 0.264 & 0.230 & 0.288 \\
\hline & $(0.0605)$ & $(0.122)$ & $(0.0669)$ \\
\hline \multirow[t]{2}{*}{85} & 0.349 & 0.316 & 0.362 \\
\hline & 0.0597 & $(0.121)$ & $(0.0659)$ \\
\hline \multirow[t]{2}{*}{86} & 0.455 & 0.508 & 0.424 \\
\hline & $(0.0584)$ & $(0.117)$ & $(0.0648)$ \\
\hline \multirow[t]{2}{*}{87} & 0.501 & 0.552 & 0.466 \\
\hline & $(0.0581)$ & $(0.116)$ & $(0.0646)$ \\
\hline \multirow[t]{2}{*}{88} & 0.533 & 0.638 & 0.479 \\
\hline & $(0.0573)$ & $(0.112)$ & $(0.0644)$ \\
\hline \multirow[t]{2}{*}{89} & 0.557 & 0.694 & 0.486 \\
\hline & $(0.0573)$ & $(0.112)$ & $(0.0645)$ \\
\hline \multirow[t]{2}{*}{90} & 0.511 & 0.638 & 0.441 \\
\hline & $(0.0579)$ & $(0.113)$ & $(0.0651)$ \\
\hline \multirow[t]{2}{*}{91} & 0.489 & 0.642 & 0.404 \\
\hline & $(0.0583)$ & $(0.114)$ & $(0.0659)$ \\
\hline \multirow[t]{2}{*}{92} & 0.675 & 0.847 & 0.576 \\
\hline & $(0.0571)$ & $(0.112)$ & $(0.0645)$ \\
\hline \multirow[t]{2}{*}{93} & 0.651 & 0.836 & 0.555 \\
\hline & $(0.0577)$ & $(0.113)$ & $(0.0648)$ \\
\hline \multirow[t]{2}{*}{94} & 0.698 & 0.871 & 0.622 \\
\hline & $(0.0573)$ & $(0.113)$ & $(0.0641)$ \\
\hline \multirow[t]{2}{*}{95} & 0.679 & 0.858 & 0.600 \\
\hline & $(0.0578)$ & $(0.114)$ & $(0.0645)$ \\
\hline \multirow[t]{2}{*}{96} & 0.720 & 0.937 & 0.621 \\
\hline & $(0.0587)$ & $(0.116)$ & $(0.0655)$ \\
\hline \multirow[t]{2}{*}{97} & 0.706 & 0.895 & 0.625 \\
\hline & $(0.0587)$ & $(0.118)$ & $(0.0652)$ \\
\hline \multirow[t]{2}{*}{ _cons } & 0.763 & 0.671 & 0.734 \\
\hline & $(0.0771)$ & $(0.130)$ & $(0.104)$ \\
\hline Log Likelihood & $-15,768.6$ & $-5,772.1$ & $-9,941.7$ \\
\hline Observations & 2,988 & 1,071 & 1,917 \\
\hline
\end{tabular}


Table 3

Measuring Spillovers to Japanese Firms

Negative Binomial Regressions

Dependent Variable: Citations

Obs $=1,857$

\begin{tabular}{|l|l|}
\hline \multicolumn{2}{|c|}{ Fixed Effects } \\
\hline $\log$ R\&D & -.020 \\
$\log$ U.S. patents & $.014)$ \\
& .847 \\
Proximity & $(.016)$ \\
& .579 \\
& $(.085)$ \\
U.S. alliances & $\mathbf{. 0 0 4}$ \\
Time Dummies & $\mathbf{( . 0 0 2 )}$ \\
Log Likelihood & Yes \\
& -6440.5 \\
\hline
\end{tabular}

Source: Branstetter (2001b) 
Table 4

Do Increased Knowledge Flows Raise Innovative Productivity?

Negative Binomial Regressions

Dependent Variable: Citation-adjusted patent output

\begin{tabular}{|l|cl|}
\hline \multicolumn{2}{|c|}{ Fixed Effects(1) } & Random Effects(2) \\
\hline $\log$ R\&D & .031 & .023 \\
log real sales & $(.021)$ & $(.027)$ \\
& .011 & .101 \\
$\log$ U.S. patents & $.034)$ & $(.036)$ \\
& .956 & .822 \\
log citations to U.S. & $(.016)$ & $(.021)$ \\
Patents & $\mathbf{. 0 0 0 1}$ & \\
Dummy for citation & $\mathbf{( . 0 0 0 0 2 )}$ & \\
Greater than median & & $\mathbf{. 8 9 9}$ \\
Time Dummies & & $\mathbf{( . 0 9 6 )}$ \\
Log Likelihood & Yes & Yes \\
Observations & $-6,119.5$ & $-7,884.8$ \\
& 2,066 & 2,160 \\
\hline
\end{tabular}




\section{Appendix: Data Sources}

This data appendix briefly describes our data sources.

Japanese Patent Data. Japanese patent data are from PATOLIS, an on-line patent database maintained by the Japan Patent Information Organization (JAPIO). The data are counts of patent applications by firm and year.

US Patent Data. The data on patents taken out in the United States by Japanese firms are from the NBER Patent Database, described in Hall, Jaffe, and Trajtenberg (2001). The data include counts of patent grants by firm and year. In work the patents are dated by the year of application rather than the year of grant. We also include a firm-specific measure of patent output that is quality-adjusted by counting subsequent citations received by these patents, as described in the text.

$R \& D$ data. The overall R\&D spending of individual Japanese firms is taken from several consecutive issues of the Kaisha Shiki Hō, published by Toyo Keizai, and the Nikkei Kaisha Jōhō, published by the Nihon Keizai Shimbunsha. All R\&D expenditure data is deflated by the R\&D price index constructed by the Japanese Science and Technology Agency and reported in Gijutsu Yöran.

Other firm variables. Data on firm sales and industry affiliation and are taken from various issues of the Japan Development Bank Corporate Finance Database. Data on R\&D alliances with US firms are taken from the Securities Data Corporation (SDC) joint ventures database.

Sample Selection Issues. Firms were selected on the basis of availability of a sufficient quantity of R\&D data and patent data in both Japan and the United States. We further required that there be no major jumps in such series as capital stock over the course of the 1980s, thereby screening out firms involved in major domestic mergers or acquisitions. This means handful of large R\&D performers are omitted due to data irregularities. The screening tends to over-sample $\mathrm{R} \& \mathrm{D}$ intensive firms relative to the population as a whole. A complete list of the firms in our sample and additional information on the sample are available from the authors on request. 